\title{
Tiyatro ve Sinema Uyarlamaları Bağlamında Zaman-Uzam ve İmgelerin Söyleşimi: Federico Garcia Lorca Örneği
}

\author{
Aslı Şahinkaya*
}

Özet

Bu çalışmanın düşünsel ikliminin uzlaşımına göre imge, soyut ya da somut bir varlı̆̆ın zihindeki izdüşümü olarak tanımlanabilir. Bu bağlamda yazılı bir metinle, görüntüsel bir imgenin ve 'gerçek hayat' imgelerinin zihindeki izdüşümü hangi noktalarda farkhlaşır sorusu, bu çalışmanın ana eksenini oluşturmaktadır. Mihail Bakhtin, edebiyatın fiili gerçekle ilişkisinin zaman-uzamla kurulabileceğini söylemektedir. Tam da bu noktada bir yapıtın zaman-uzamı yani kronotopu, imgelerin birbirleriyle kurdukları merkezcil ve merkezkaç ilişkiler bütünü çerçevesinde belirir. Bu çalışmada imgelerin birbirleriyle kurdukları diyaloğun ortaya çıkardığı ilişki ağları üzerinden; yazınsal imgelerin, görüntüsel imgelere dönüşümünde, uyarlanmasında, imgelerarası söyleşim sürecinin izlediği patikalarn izi sürülecektir. Bu bakış, uyarlama çalışmaları ve kuramını ve temel pratiklerini tartışmayı beraberinde getirmektedir. Bu çalışmada, edebi bir metinden uyarlanmış bir sinema metni üzerinden farkh ve yaratıc bir uyarlama mümkün müdür, bu noktada imgeler, zaman- uzam bă̆lamında, birbirleriyle nasıl diyalog kurarlar ve nasıl birbirlerine dönüşürler soruları tartışlacaktır.

Sinema ve tiyatro senaryolarının yazılı olmasından dolayı ortaklaşan ancak gösterim biçimleri dolayısıyla "techne" bakımindan birbirinden ayrilan görsel sanatlardır. Hem bir tiyatro oyunu hem de bir sinema filminin senaryolarn yazınsal olarak üretilir, ancak uygulama aşamasında görsel imgelerle sözcükler imlenirler. Bu karmaşık metinlerarası ilişkinin, imgelerin söyleşim sürecini çok katmanlı hale getirmesi dolayısıyla bu çalışmada bir tiyatro metninin sinemaya uyarlanmasını incelemek ilginç bulunmuştur. İspanyol yazar ve şair Federico García Lorca'nın tragedyalarından biri olan Bernarda Alba'nın Evi adlı oyundan sinemaya uyarlanan iki film kuramsal eksende incelenecek ve imgelerin birbirleriyle kurduğu ilişkiler takip edilerek imgeler arası söyleşimin yaratıcı boyutları üzerine düşünceler üretilecektir.

Anahtar Kelimeler: Sinema, Tiyatro, Metinlerarasılık, Federico García Lorca

ORCID ID : 0000-0003-1287-4453

E-mail : asli.sahinkaya@gmail.com

DOI: $10.31122 /$ sinefilozofi.516349

Geliş Tarihi - Recieved: 22.01.2019

Kabul Tarihi - Accepted: 30.04.2019 


\title{
Time-Space in the Context of Theater and Cinema Adaptations and Dialogism of the Images: The Case of Federico Garcia Lorca
}

\author{
Aslı Şahinkaya*
}

\begin{abstract}
According to the conception of the intellectual climate of this work, the image can be defined as the projection of an abstract or concrete entity in the mind. In this context, the question of where a projected image and bu real life 'imagery differs in mind in a written text constitutes the main axis of this study. Mihail Bakhtin says that the relation between literature and actual reality can be established with timespace. At this point, the time-space, the chronotopia of a work appears within the framework of the centripetal and centrifugal relations that images establish with each other. In this study, through the relationship networks revealed by the dialogue between images; In the transformation of the literary images into the imaginary images and their adaptation, the paths followed by the intersection process will be followed. This view brings about adaptation studies and discusses the theory and basic practices. In this study, a different and creative adaptation is possible through a film text adapted from a literary text, at which point the images will be discussed in the context of time-space, how they communicate with each other and how they are transformed into each other.

The visual arts which are shared by cinema and theater scenarios but separated from each other in terms of their technicalities due to their representations. The scripts of both a theater play and a film are produced as literary, but visual images and words are marked in the application phase. In this study, it was found interesting to examine the adaptation of a theater text to the cinema as this complex intertextual relationship rendered multi-layered images of images. Two films adapted from the play named House of Bernarda Alba, one of the tragedies of the Spanish writer and poet Federico Garcia Lorca, will be examined in the theoretical axis and thoughts on the creative dimensions of the interimage dialogue will be pursued by following the relations of images with each other.
\end{abstract}

Keywords: Cinema, Theater, Intertextuality, Federico Garcia Lorca

ORCID ID : 0000-0003-1287-4453

E-mail : asli.sahinkaya@gmail.com

DOI: 10.31122/sinefilozofi.516349

Recieved - Geliş Tarihi: 22.01.2019

Accepted - Kabul Tarihi: 30.04.2019 


\section{Giriş}

İmge, farklı yaklaşımlara göre, çok farklı anlamlar kazanır. İmgenin nasıl tanımlandığı ise, aslında dünyanın epistemolojik olarak nasıl değerlendirildiğinin en temel belirleyenidir. Çünkü aslında insan düşüncesinin temel birimini imgeler oluşturur. Bu çalışmada imge kavramı, soyut ya da somut bir varlığın zihindeki izdüşümü olarak tanımlanmaktadır. Tabii imgenin, çok daha geniş kapsamlarda ele alınması gereken fenomenolojik bir mesele olduğunu hatırlatmak gerekir. Günlük hayatta, algıyı oluşturan, belirleyen şey imgenin ta kendisidir. İmge karşımıza her seferinde farklı formlarda çıkar, görsel, işitsel, yazınsal, dijital. Çağımız imgeleri birbirinden, dünyadan ve insan zihninden kopararak ele alınmasının mümkün olmadığı bir çağ olduğunu söylemek mümkündür.

Dil, söylem ve izlemenin (viewing) bir sentezi olan imgeler bütün medya biçimlerini bir araya getiriyor. İmgeler, pek çok ifadenin arasında yalıtılmış birer ifade olmadıklarn gibi, sadece nesne ya da gösterge de değiller elbette (...) Başka bir deyişle, imgeler uçsuz bucaksız ve birbirine bağgl imgedünyalarn hem atasıdır hem de sonucu (Burnett, 2012: 31).

Çeşitli medya kanallarıyla, ekranlarla, hareketli ya da durağan imgeler hayatımızın her yerindedir. Dolayısıyla imgeyi, düşünceyi ve iletişim araçlarını birbirinden ayrı düşünmek olanaksızdır. Ancak şu ayrımı unutmamak gerekir, imge üretimi, enformasyon üretiminden farklı bir süreçtir. Yalnızca o değil ancak genellikle imgeleri sanat üretir. İmge üretimi, iletişimden çok başkadır. "Sanat eseri bir iletişim aracı değildir. Sanat eserinin iletişimle işi olmaz. Sanat eseri en ufak bir enformasyon kırıntısı bile içermez" (Deleuze, 2003:38).

Sinema ise aslında, yazının bize sunduğunun ötesinde daha karmaşık bir imgeler yelpazesi sunmaktadır. Sinema, birçok çeşitli imgenin bir araya gelerek iç içe geçtiği, birbirinin içinde eridiği, yer yer yok olup, yer yer yeniden doğduğu zaman-uzamlara imkân tanır. Bu nedenle sinemanın imgeleri üzerine düşünürken, göçebe imgelerden, birbirlerine dokunan, hayata, gerçeğe ve rüyalara dokunan imgelerden söz etmek mümkündür. Sinema, imgelerle beraber aslında zaman-uzamı da dönüştürür, sürekli yeniden var eder. İster insan zihninin ürettiği imgeler olsun ister sanatla, bilimle üretilmiş olsun; imgeler ve zamanuzam arasında sıkı sıkıya bir ilişki vardır. Zaman-uzamın dönüşmesi ve her defasında yeni bir katmana taşınması da yaratıcı eylemin kendisidir. Deleuze İki Konferans'da Bresson'un filmleri için şöyle söylüyor: “Bir dizi küçük mekân kırıntısı, mekân parçacıkları... bağlantıları ise önceden belirlenmiş değil.(...) Ama Bresson her durumda, birbirleriyle bağlantısız küçük mekân parçacıklarından önceden belirlenmemiş mekân yaratan ilk sinemacıdır. Ve şunu söylemeliyim: Her yaratımın sınırında, ufkunda mutlaka mekân-zamanlar vardır" (Deleuze, 2003: 23).

İşte tüm bu bağlantılarla birlikte sinemada başka sanatlarda bir arada bütünsel olarak var olamayan bir şeyden söz edilebilir, hareketli imgelerle iş gören sinema, zihnin işleyişine en yakın sanat alanıdır. Bundan dolayı da zihnin imge ürettiği gibi imgeler üretmektedir. Henri Bergson'a göre, hepimiz şeyleri yalnızca imgeler biçiminde kavrarız ve zihnimiz bu biçimde işler (Bergson, 2015).

Bu imgelerin algılanması ise ancak hareketle, titreşimle mümkün olmaktadır. Deleuze' ün 
(2014) sözünü ettiği hareket imge kavramı aslında açık bir bütünün insan zihni tarafından algılanmasını sağlayan titreşimi ortaya koyan, hareket bloklarıdır. Değişimi sağlayan da bu hareketin kendisidir.

Demek ki benim bedenim de maddi dünyanın içinde diğer imgeler gibi hareket eden, hareketi alı veren bir imgedir. (...) Nesneleri değiştirin, benim bedenimle ilişkilerini değiş̧tirin: bu durumda benim algı merkezlerimin içsel hareketlerindeki her şey değişmiş olur. Ama aynı zamanda 'benim algım' içinde de her şey değişir. Demek ki, benim algım, bu moleküler hareketlerin bir fonksiyonudur, onlara bağhıdır (Bergson, 2015: 17-19).

İmgelerin hareketi, her defasında zaman-uzamın dönüşmesini sağlar denebilir. Bu da her imgenin kendi ilişkilerini daima yeniden kurduğu ve dönüştürdüğü bir zihin yapısını beraberinde getirmektedir. Sinema da gerçeğin zihindeki etkisini, zihindekinin perdeye etkisine dönüştürmektedir. Yaşamı yaşayış biçiminin bir benzeri olarak sanat da aynısını yapmakta ve çevredeki imgeleri, zihnin süreçlerine katıp başkalaştırmakta, sonra da onlara yeniden form vererek ortaya koymaktadır. Sonra ortaya koyulan imgeler sistemi, başka zihinlerin işleyişine açılmakta ve metin her defasında yeniden var olmanın bir yolunu bulmaktadır. İmgenin bu yolculuğunun ne karmaşık bir ilişki olduğu ortadadır.

(...) söz konusu dünyayı, metni yaratan dünya olarak adlandırabiliriz.; zira tüm boyutlar metinde yansittlan gerçeklik, metni yaratan yazarlar, metin icracilarn (şayet mevcutsa) ve bir de, metni yeniden yaratan ve bu yolla metni yenileyen dinleyiciler ve okuyucular-metinde temsil edilen dünyanın yaratımına eşit ölçüde katılırlar (Bahtin, 2014: 307).

Bir metnin oluşumu, hangi türde olursa olsun benzer süreçlere tabiidir. Bir metin ortaya koymak; bu ister bir şarkı, ister bir resim, ister bir edebi metin olsun; göçebe imgeleri toplayarak, onlara yeni bir zaman-uzamlar kazandırmaktır denebilir. Bahtin'in metinlerarasılığı tam da bu noktada şöyle yorumlanabilir; her üretim, farklı imgelerden devşirilmiş bir, bir araya getirmedir. Bu süreçteki etkin elemanların hepsine göre- oyuncu, yazar, yönetmen, ressam, izleyici, dinleyici, besteci, senarist vs. dönüşebilen bir zaman-uzam kavramı olduğunu da hatırlatmak gerekir. Bu çalışmada da aslında ele alınan mesele, imgenin türler arasındaki yolculuğu yani imgelerin birbirine uyarlanmasıdır.

Uyarlama ile ilgili sayısız miktarda kuramsal çalışma bulmak olasıdır. Sinema kuramcıları, edebiyat kuramcıları, dilbilimciler, tiyatro kuramcıları geçmişten günümüze uyarlamalar ile ilgili çalışmaktalardır. Literatürün geneli incelendiğinde, bütün uyarlama yaklaşımları mutlaka bir sanat alanını, diğerine karşı hiyerarşik olarak üstün bir noktada ele aldıkları görülmüştür. Ortak bir uzlaşı ile, kaynak metin ${ }^{1}$ ya da ilk metin adını verdikleri metin, her zaman uyarlama metnin değer ve nitelik bakımından üstünde kabul edilmiştir. Bu da aslında bir diğer mecradaki yaratıcılığın görmezden gelinmesi, diğer mecranın "techne" sine yönelik küçümseyici bir bakışın ürünüdür denebilir.

$\mathrm{Bu}$ çalışmanın sorunsalını uyarlamanın yaratıcı bir edim olduğu ve imgelerin yer değiştirdiği her mecrada yeni edimler kazandığı fikri oluşturmaktadır. Bu araştırmanın sorunsalını ortaya koyma sürecinde merak konusu olan ilk soru, niçin hala uyarlama yapılıyor ve niçin hala izleniyor sorusudur. Çünkü aslında bütün imgeler birbiriyle ilişki içinde var

1 Kaynak metin ifadesi, bu çalışmada ele alınan yaklaşımla doku bakımından uyumlu değildir. Çünkü hiçbir metnin, dolaşım halinde olan imgenin kaynağı olamayacağı düşünülmektedir. Ancak uyarlanan metinde anılan metin referans kabul edildiği için, metin boyunca sözcük kullanılmış olup uyumsuzluk konusundaki farkındalığın belirtilmesi adına italik yazılması tercih edilmiştir. 
olmakta ve bir uyarlama çalışması, imgeyi bağlamından söküp alarak onu yeni bir formda, yeni bir bağlamın zaman-uzamına taşımaktadır. Bu da yeni bakış açıları, yeni zaman-uzamların keşfi ve yeni düzeyler, yeni dünyalar demektir.

Ancak imgenin hiçbir zaman tümüyle daha önceki bağlantılarını kaybetmediğini, içinde bulunduğu tüm zaman-uzamları üstünde taşıdığını da hatırlamak gerekmektedir. Hem yeni metinde hem de kaynak metinde zaten hep akış halinde olan bir anlam dizgesinden söz etmek mümkündür. İmge bunu içinde taşır ve her bağlamda yeniden başkalaşarak anlamı sürdürür. Tam da bu bağlamda insanlığın ortaya koyduğu tüm metinler hem doğayla hem de önceki ortaya konmuş metinlerle metinlerarası bir ilişki içindedir. Ancak bu durumda hala bir şeyleri yeni k1lan, edimsel olarak formda var olan farklı kanallar, yeni yolların bir araya getirilme imkânıdır. Yaratıcılığın kaynağı, imgenin bu zaman-uzam içindeki dolanımı, yer değiştirmesi, göçü, mücadelesi, kendini var etme çabasıdır.

İmge dolaşımda olduğu süre boyunca çevresiyle ilişkisinde sürekli bir mücadele halindedir. Metnin dünyası, dış dünya ile ilişkilidir ancak tamamen onunla aynı değildir; metin, gerçek dünyanın yalnızca bir temsili değil, aynı zamanda onun anlamlarını ve katmanlarını çoğaltan, yeni bir bakış açısıdır. Bu süreçte bu yaratıcı katmanları ortaya koyan, her defasında imgeleri başkalaştıran da okurun ta kendisidir. Burada okur, yazar, metin ve imgelerin doğal dünyası arasında sürekli gerçekleşen bir mübadele sürecinden bahsetmek mümkündür (Bahtin, 2014).

Tüm yaklaşımlarla beraber tragedyalar ele alındığında, mesele daha da ilginçleşmektedir. Tragedya, bir tür olarak, Aristoteles'in yaptığı ilk ve klasik tanımından da hareketle; biçimsel anlamda düzenli kurallar çerçevesinde inşa edilmiş, soylu karakterlerin kendi yazgılarıyla girdikleri mücadele sonucu yıkıma uğradıkları, evrensel değerlerin ve erdemin ışığında kurulmuş, izleyicinin/okuyucunun acıma duygusunu sağaltmak için ortaya konan şiirler olarak tanımlanabilirler (Aristoteles, 2014). Bu bağlamda klasik dönemden Shakespeare (Kimi eserleri), Sophokles, Euripides gibi yazarların eserleri trajik eserler olarak nitelendirilebilir. Tragedyaların genellikle sahnelenmek üzere yazılmış olmaları öngörülür. Ancak her ne kadar bir tragedyay 1 tragedya yapan temel niteliklerden biri sahnelenmesi olsa da, bunun aksi durumlar da söz konusu olabilir.

Gösteriye gelince, işin çekici yanını oluştursa da aslında yabancıdır bu sanata; şiir sanatı için en az gerekli olanıdır. Tragedya, etkisini yarı̧̧asız, oyuncusuz da gösterebilir. Ve gösterinin düzenlenmesi, ozanın sanatından çok, dekorcunun sanatın ilgilendirir (Aristoteles, 2014: 32).

Sahnelense de sahnelenmese de tragedyalar, içerik ve biçim açısından keskin sınırları olan yazınsal metinlerdir. Peki Federico García Lorca'nın metinleri, çoğunlukla biçimsel olarak tragedyanın formuna uymadığı halde nasıl tragedya olarak kabul edilebilir? Çağdaş tragedya adı verilen bu tragedya biçimi, adı üstünde çağcıl metinlerle beraber var olan ve çağımıza seslenen metinlerdir.

Böyle de olsa modem tragedyanın belli başlı bir iki özelliğine değinmek gerekir. Çağlar değiş̧ikçe, insanın evrendeki yeri üzerine olan düşüncelerinde de değişiklikler olmuştur. Modern tragedyanın kahramanları artık krallar, prensler ve tiranlar değildir. Modern tragedya kahramanları yaşamımız içinde pek göze çarpmayan olağan insanlardır (Nutku, 2001: 55). 
Lorca'nın çağdaş tragedya olarak nitelendirilen yapıtlarında da -Yerma, Bernarda Alba'nın Evi, Kanlı Düğün- karakter günlük hayatın içinden, sıradan insanlardır. Bu metinler, hangi çağda olurlarsa olsunlar yazgılarına, toplumun yozlaşmış ahlak kurallarına karşı gelen ve sonuçta özgürlüklerinin bedelini ölümle veya daha farklı yıkımlarla ödeyen ve yaşamı çelişkilerle dolu çağdaş insanı konu edinir.

Tragedya seyreden kişi hem bir izlenimler kargaşası altında ezildiğini hisseder, hem yaşam hakkında derinliğine düşünmenin ve bilgilenmenin gururunu tadar. Özünde trajik olan, insanın her şeyden önce çelişkili bir dünyada yaşamak ve eylemek zorunda olması ise, kimi modern oyunlarda da trajik olandan söz edebilmeliyiz (Şener, 2016: 105).

Bu noktada biçimsel olarak başkalaşmasına rağmen tümüyle değişmeyen bir insan yazgısından söz etmek mümkündür. Bu nedenle çalışma konusu olarak çağdaş tragedya metinlerini incelemek ilginç bulunmuştur. İnsanın değişmeyen trajedisi, metinlerarası biçimde çağın içinde yerini almaktadır. Bütün tragedyalar insanın trajedisinden yola çıkar ancak hepsi farklı tatlar sunar, farklı yollar kullanırlar. Bu da tragedyanın her çağda yazılması, okunması ve uyarlanmasinin temel nedeni olarak ortaya atılabilir.

Bu çalışmada her ikisi de yazınsal bir metinden uyarlanan sinema ve tiyatro sanatlarının birlikte ele alınması, "techne"leri bakımından yeni imgeler ortaya koyma imkânlarını ve üretim süreçlerinin kendilerine özgü ara yüzlere göre nasıl dönüştüğünü görebilmek dolayısıyla ilginç bulunmuştur. Bir tiyatro oyunun sahnelenmesi de tıpkı bir sinema filmi gibi yazınsal bir metnin uyarlanmasıyla gerçekleşir. Uyarlama çalışmalarında genellikle dışarıda bırakılan unsur da budur, öyküsü bir edebi metne dayanmasa dahi, her filmin bir senaryo metni vardır. Metinlerarasılık ilişkisine bir yenisi daha eklendiğinde, uyarlama sürecinin çok katmanlılığ da belirginleşmeye başlamaktadır. Özünde her yeni metnin bir içkinlik düzlemi (Deleuze, 2014); kendine özgü bir kronotopu, yani zaman-uzamı (Bahtin, 2014) vardır.

Öte yandan, Lorca'nın hem bir tiyatro yazarı hem de tiyatro kuramcisı olması, bu çalışmadaki tiyatro/yazı ara yüzünü destekler niteliktedir. Lorca'nın (2014) duende kavramı, bu çalışmanın kuramsal çerçevesini, içkinlik düzlemi ve yaratıcılık bağlamında desteklemekte ve çalışmanın konusuna da ilham sağlamaktadır.

Bu çalışmanın amacı, tam da sözü edilen imge, zaman-uzam ve uyarlama yaklaşımlarıyla, her defasında daha yaratıcı, teknolojinin olanaklarının daha özgün kullanımıyla; binlerce yıldır insanın değişmeyen trajedisine bile farklı ve yaratıcı kılan bir bakışla yaklaşılabileceğini; özetle, daha yaratıcı uyarlamaların imkânını ortaya koymaktır. Uyarlama kavramına çok boyutlu bir bakış yönelterek, farklı metinler arasındaki imgesel geçişin bu bağlamda yaratıma olan etkisi tartışılacaktır.

Lorca'nın tragedyalarından, Bernarda Alba'nın Evi adlı oyundan uyarlanan La Casa de Bernarda Alba (Bernarda Alba' nın Evi, Mario Camus, 1987) ve The House of Bernarda Alba (Bernarda Alba' nın Evi, Stuart Bruge, Núria Espert, 1991) incelenmek üzere seçilmiş filmlerdir. Sınırları yukarıda çizilen çerçeveye ve ana eksene dayanılarak bu iki film incelenirken; imgelerin dönüşümünün izleri sürülecek ve sinemanın olanaklarının kullanımı bakımından 
imgelerin yaratıcı dönüşümünün çok katmanlı yolculuğu ele alınacaktır.

\section{İmgenin Yolculuğu Olarak Uyarlama}

Her metnin imgeleri vardır; "techne" si her ne olursa olsun bütün sanat yapıtları imgelerle inşa edilir. O imgelerin arasında kurdukları ilişki, dizilimleri, bir araya gelişleri ise o sanatın dili olarak nitelendirilebilir. Bu imgelerin metnin içinde birbirleriyle kurdukları bağlantılar, bulunduklar1 yer ise o metnin kronotopudur. "Edebi imgelerin herhangi biri veya hepsi zaman-uzamsaldır. Bir imge deposu olarak dil de esasen zaman uzamsaldır" (Bahtin, 2014: 304)

İmge, sürekli bir akış halindedir. İnşacı bir paradigmayla yaklaşmak gerekirse; insanların zihinlerinde var olan imgeler, insanın gerçek dünya denilen o alanı kavrayışıdır. Bir metin ortaya konulurken yazarın imgelemi ve kavrayışı, metnin alanlarına sızar, yazarın metnini işgal eder. Çünkü imgelem, yazarın metnini ortaya koyduğu ana malzemedir. İmgenin akışı metni de aşar ve okuyucunun imgelemine akar. "İmge, bu katedilen yolun kendisidir, oluş olmuştur" (Deleuze ve Guattari, 2000: 32) Sürekli oluş halinde olan bu imgeler sistemini Bergson'un evren algısından söz ettiği şu ifadeleriyle düşünmek ilham vericidir:

İşte, "benim evren algım" dediğim ve ayrıcalıklı belli bir imgenin- bedenimin- hafifçe değişimleriyle tepeden tırnağa altüst olan bir imgeler sistemi! Bu ayrıcalıkl imge merkezde bulunur; tüm diğerleri kendilerine onu örnek alırlar; sanki bir kaleydoskobu çevirmiş gibi, her bir hareketleriyle her şey değiş̧ir. Diğer yandan, işte, yine ayn imgeler; ama bu kez kendiyle ilişkilidir; birbirini kuşkusuz etkilerler, ama sonuç daima nedenle orantılıdır: Benim evren dediğim işte budur! (Bergson, 2015: 21).

$\mathrm{Bu}$ oluş halindeki imgeler sistemini kuran yazardır ancak yazar bir araya getirdiği imgeleri kendisi yaratmaz. İmgeler zaten kültürle, dille, ideolojilerle, inançlarla yüklüdür; imge mutlaka başka bir yerden yazar tarafından koparılıp alınmış ve yeni bir zaman-uzamda yerli yurtlu hale getirilmiştir, ta ki bir kere daha yersizyurtsuzlaşana kadar (Deleuze ve Guattari, 2000).

Öte yandan Bahtin bu durumu şöyle ifade eder:

Dilde katmanlaşmaya yol açan tüm güçlerin etkinliklerinin bir sonucu olarak, hiçbir nötr sözcük ve biçim yoktur: "Hiç kimseye" ait olmayan sözcük ve biçimler yani; dil tamamen ele geçirilmiş amaçlar ve vurgularla doldurulmuştur. (...) her sözcük, toplumsal olarak yüklü hayatını sürdürmekte olduğu bağlamın ve bağlamların tadını alır; tüm sözcükler ve biçimler amaçlarla doludur (Bahtin, 2014: 69).

Bu nedenle öncelikli olarak imgenin, gerçek hayat da denilen dış dünya ile yazarın zihninden aldığı hareketlilikle dönüşümü söz konusudur. Sonrasında imgelerin birbirleriyle metin içindeki hareketliliği, anlamı devamlı olarak dönüştürür ve başkalaştırır. Sonuçta her metin bir izleyiciyle, okuyucuyla tamamlanır ya da canlii yaşan bir şey haline gelir. Okuyucunun zihnindeki imgeler sisteminden süzülen imgeler sistemi. Son derece karmaşık ancak, yaratıcı bir süreç olduğu söylenebilir. Bir de bu sürece, o metni okuyup sonrasında onu farklı bir alana uyarlamaya çalışan bir göz daha eklendiğinde, imgenin yolculuğunun dolambaçlı yollarını 
izlemenin güçleştiğini söylemek mümkündür. Tam da bu nedenle, uyarlamanın sanıldı̆̆1 gibi kaynak metinden hikâyenin aşırılıp, farklı bir mecraya, aktarılması kadar basit bir süreç olmadığı söylenebilmektedir.

Uyarlama, her ne biçimde olursa olsun, imgeyi üretildiği mecradan bir diğerine taşımak değildir. Uyarlamayı yapan kişi, kaynak metinden imgeleri alıp yeni bir dil formuna sokmaktan fazlasını yapar. Uyarlamayı yalnızca kaynak metne tam sadakat gösterilen bir faaliyet olarak ele alan bakış, uyarlamayı yapanın yaratıcılığını ve imgenin uyarlandığı yeni mecranın kendine özgü olanaklarını göz ardı etmektedir. Uyarlamaya olan bu katı yaklaşım, hala edebiyat, sinema ve tiyatro alanlarında varlığını sürdürmektedir. Peki uyarlamaların hala yeni anlamlandırma süreçlerine açık olmasını sağlayan nedir? Aynı soru beraberinde uyarlamaların neden hala tercih edildiğini getirmektedir. Eğer uyarlama kaynak metne tam sadakat göstererek oradaki referansları olduğu gibi diğer mecraya aktarmak olsaydı bu, eylemin örneğin sinemada yönetmenin yalnızca bir pratisyen olmasını ve ürettiği yeni metnin diğerinin bir taklidi olmasını gerektirirdi.

Öte yandan bu türlü yaklaşımlarla üretilmiş uyarlama metinlerin olduğunu da belirtmek gerekmektedir. Bu türlü yaklaşım, tıpkı gelenekçi uyarlama kuramlarında olduğu gibi, uyarlamayı bir metinden diğerine yapılan bir aktarım gibi nitelendirmektedirler. Bu dolayımla sadakat tartışmaları kendini göstermeye başlar. Sinema özelinde yoğunlaşırsak, yönetmenin tek amacı, yazınsal metni olduğu gibi perdeye aktarmakmış ön kabulüyle, yönetmenin verdiği her türlü katkı ve değişiklik, edebi metne bir ihanet gibi değerlendirilebilmektedir. Ancak fiziksel nedenlerle bile, gerçeklikteki bir olayı bir metne ya da benzer bir biçimde bir metni farklı bir mecraya olduğu gibi aktarmak olanaksızdır.

Kendimle, benim kendi "Ben"imle öykülerimin öznesi olan "Ben" arasında özdeşlik kurmak, tıpkı kendimi kendi saçımdan tutup kaldırmak denli imkânsız olacaktır. Temsil edilen dünya, ne denli gerçekçi ve aslına sadık olursa olsun, asla temsil ettiği gerçek dünyayla, edebi yapıtın yazarı ve yaratıcının bulunduğu gerçek dünyayla, zaman-uzamsal olarak özdeş olamaz (Bahtin, 2014: 310).

\section{Metinlerarasılık, Zaman-Uzam ve İmgelerin Söyleşimi}

Metinlerarasılık (intertextuality) kavramı, öncelikle dilbilim, biçembilim alanlarında doğmuş ve yazınsal metinler üzerinden farklı kuramcılar tarafından farklı şekillerde adlandırılarak incelenmiştir. Kimi kuramcılar konuyu yapısalcı bir bakış açısıyla ele alırken kimileri post-yapısalcı alana taşımışlar ve metinlerarasılığı metinlerden koparıp hayatın içine yerleştirmişlerdir. Ne biçimde bakılmış olursa olsun, metinlerarasılık, bir sözcüğün, bir imgenin her zaman daha önceki bağlamları üstünde taşıyarak başka alanlara taşındığını savunur; yani kısaca ifade etmek gerekirse, hiçbir şey ilk defa söylenmemiştir.

Sonuçta, La Bruyere'in belirttiği gibi, "Her şey söylenmiştir" İlk metinden geriye bir kopya kalmıştır. İlk kez kağıt üzerine yazılan şeyler sonradan silinmeye çalışılmışsa da yine de geriye ilk yazıdan izler kalmıştır. Palempsest kuramına göre yeni icat edilen şey aslında yalnızca daha önce söylenilişine dayanır, onun yinelenmesinden başka bir şey değildir. Yazmak yeniden-yazmak ve başka yapıtları okumaktır. Yazın, bir palempsest'tir (Aktulum, 2000: 21) 
Kubilay Aktulum'un yukarıdaki alıntıda söz ettiği Palempsest ya da Palimpsest ${ }^{2}$ olarak bilinen kavram ait metinlerarasılığı ifade eden bir kavramdır. Aslında palimpsest eski çağlarda metinlerin yazıldığ parşömenlerin bir türüne verilen addır. Fakat Genette, kavramı metaforik biçimde ele almış ve daha önce yazılmış yazıların silinip üzerine yeniden yazılması dolayısıyla palimpsesti imgenin yolculuğunu somutlaştırmak için kullanmıştır. Burada metinlerarasılığı ifade etmek için kullanılan palimpsest, eski bir imgenin yeni bir imgeye katılması olarak tanımlanmaktadır. Yeni bir metin, imgelerini o düzleme taşıdığında, eskiler tümüyle yok olmaz; yeni, eskiye katılır ve bambaşka bir anlam ve form kazanır (Aktulum, 2000).

İmgelerin, her zaman geçmişteki kullanımlarını özlerinde taşıdıklarını anlatmak adına çok iyi bir örnek olduğunu söylemek mümkündür. Gerçekten de dünyada var olan her şey, bir diğerinin etkisiyle, titreşimiyle, hareketiyle var olur ve var olan her şey bir diğerinin izini taşır. Öte yandan kavramla ilişkili iki temel isimden söz etmek mümkündür: Julia Kristeva ve Mihail Bahtin.

İki düşünürün yaklaşımı da birbiriyle benzeşmektedir. Zaten Aktulum'a göre (2000), Kristeva, Bahtin'in fikirlerini alarak Fransız düşün dünyasına uyarlamış ve Avrupa'ya yayılmasını sağlamıştır. Krsiteva metinlerarasılığı tanımlamak için mozaik metaforunu kullanmıştır. Ona göre, metin gösterenleri bir araya getiren bir düzlemdir, sonra o gösterenler farklı bağlamlara girerek yeni anlamlar kazanırlar. Aktulum'un (2000) Krsiteva' dan aktardığ1 gibi: "Her metin bir alıntılar mozaiği gibi oluşur, her metin kendi içinde başka bir metnin eritilmesi ve dönüşümüdür"'.

Mozaik benzetmesinin de tıpkı palimpsest gibi, metinlerarasılık kavramını açılamada ve anlamlandırmada son derece yerinde olduğu söylenebilir. Her metin farklı imgelerin, farklı dizilimlerle bir araya gelmesiyle oluşur. Zaman-uzam, imgelerin bir araya gelip kendilerine yer buldukları düzlemdir, metnin kendisi zaman-uzamdır. Ancak bu mozaik parçaları katı ve durağan değillerdir; imgeler bu mozaik parçalarına benzetilecek olursa, onların daima hareket halinde ve dönüşen bir eksende oldukları söylenebilir. Çünkü her imge arasında, diyalojik yani söyleşimsel bir ilişki söz konusudur (Bahtin, 2014). Her imge canlıdır, bu nedenle devamlı olarak akıştadır ve hem ortamla hem diğer imgelerle ilişki içindedir.

Öte yandan metinlerarasılığı çok daha ileri bir boyuta taşıyarak; yazarın zihnindeki imgeleri oluşturan tüm diğer metinlerin, ürettiği metinde tınladığını söylemek de mümkündür. Bir yönetmenin filminde, hayatı boyunca izlediği tüm filmlerin etkisi vardır; çünkü, yönetmenin imgelemeni inşa etmede ana bir rol oynamaktadırlar.

Aslında tüm bu kuramların çerçevesinde bakıldığında uyarlama, sadece referans alınan metnin belirtilmesi ve onun kimi özellikleri korunarak, yer yer onun biçimine öykünerek veya ondan yola çıkıp onu dönüştürerek yapılır. Uyarlama çalışmalarıyla ilgili en temel problemlerden biri de taklit ya da intihal meselesidir. Ĕ̆er bir yönetmen, esin kaynağı olan filmi belirtmez ve bu film eleştirmenler, okurlar tarafından bir başka metne benzetilirse; o zaman çalıntı olduğuna dair fikirlerin ortaya atılması olasıdır. Ancak burada sorulması gereken temel soru şudur aslında; bir uyarlama çalışmasında kaynak metinle, yeni metin arasındaki benzeşim ne ölçüde olabilir? Metinlerarasılık nerede biter, uyarlama nerede başlar; intihalin bu meseledeki yeri nedir?

Uyarlama yapısal anlamda düşünüldüğünde birçok farklı biçimde yapılabilmektedir.

2 Palimpsest, yazın alanında ilk kez Gerard Genette tarafından "Palimpsestes, la litterature au seconde degre" başlıklı metninde, metinlerarasılık bağlamında kullanılmıştır. 
Bir metindeki olay örgüsü, görsel imgelerle yeni bir metin haline getirilip, sinema perdesine uyarlanabilir. Bir başka durum, biçimsel olarak birtakım nitelikleri benzeterek yeni bir yapıt ortaya konabilir. Bu durumda kaynak metindeki zaman-uzamın kullanımının, sinemanın tekniklerinin kullanımıyla yeni metin ortaya konabilir. Bu durumlardan her ikisinin söz konusu olduğu örnekler de birazcık araştırmayla bulunabilir. Ancak şu kesindir ki, edebi bir metinden görsel sanatlara uyarlanan hiçbir metin aynı kalamaz, mutlaka başkalaşım söz konusudur. Aktulum (2000), yine Genette'in kuramına gönderme yaparak, hiçbir metnin doğrudan taklit edilemeyeceğini ifade etmiştir. Ona göre ancak bir metne ait olan biçemler başka bir metinde kullanılabilir.

Tam bir benzeşimin kiplik düzeyinde de dönüşen metinlerde söz konusu olmadığı bir ortamda, metne sadakat denen meselenin ne derece mümkün olduğu da tartışılması gereken bir meseledir. Edebi metinden sinemaya uyarlanan bir metin neden metne sadık kalmalıdır ve zaten ne kadar kalabilir? Metne sadık kalırken, kendi "techne" sine sahip olan sinemaya sadakatsizlik yapmış olmaz mı? Kanımca, yeni bir şey söylemeyecekse, bir metni ortaya koymanın pek de bir anlamı yoktur; aynısı uyarlama için de geçerlidir. Kaynak metinden daha farklı söylemenin yollarını aramak, işte budur yaratıcı üretim.

Özel olarak ilgi duyduğum soru şu: Bir sinemacıyı, sözgelimi bir roman sinemaya uyarlamaya gerçekten niyetlendiren nedir? Besbelli ki, böyle bir girişim, sinemaya özgü fikirlerin ancak romanın roman fikri olarak sunduğu fikirlerle titreşime girmesinden kaynaklanır. Ve bu noktada, çok büyük karşılaşmaların sıklıkla gerçekleştiği görülür. Burada, açıkça vasatın altında olan bir romanı uyarlamaya çaba gösteren bir sinemacının durumundan bahsetmiyorum. Bir sinemacı zayıf bir romanı uyarlama ihtiyacı duyabilir, bu da ortaya çıkacak filmin çok iyi olmasını engellemeyecektir (Deleuze, 2003:26).

Şüphesiz bu süreci ortaya koyan sac ayağından biri de okur/izleyicidir. Yazınsal bir metinden, sinemaya uyarlanma iddiası taşıyan bir metinde imgenin uğrak noktası olan birçok metin ve zaman-uzam söz konusudur. Okurun etkinlik düzeyi, metne katılması ve kendi birikimleri; metnin imgelerini alımlayıp dönüştürmesinde son derece etkindir.

\section{Tiyatrodan Sinemaya İmgenin İzini Sürmek}

Lorca, Bernarda Alba'nın Evi'ni kendi zihinsel süreçleri, içinde bulunduğu toplum, kültür ve bireysel olarak sahip olduğu imgelem ile ortaya koymuştur. Bernarda Alba'nın Evi, yazıldığı günden bu yana belki sayısızca kez tiyatro sahnesine uyarlanmıştır. Bir tiyatro oyununun uyarlanmasında kimler etkindir? Yalnızca yönetmen değil, oyuncu, dekorcu, sesçi, 1şıkçı ve diğer yapım elemanları. Hepsi eşit düzeyde bu süreçte etkindir. Çünkü yeni bir zaman-uzam yaratımında her bir unsur için etkin olarak çalışırlar. Oyun senaryosunu kimin düzenlediği, hangi bölümleri çıkarıp, hangi noktaları öne çıkardığı; yönetmenin ana tema olarak neyi vurgulamak istediği; oyuncunun karakteri nasıl yorumladığı ve onun niteliklerini sahneye nasıl taşıdığı; dekorcunun atmosferi nasıl imgelediği; ışıkçının hangi noktalara vurgu yapmak istediği ve izleyicinin imgelem dünyasını nitelikleri, ne düzeyde metne katıldığı ve onu dönüştürdüğü gibi. Görüldüğü gibi son derece kritik birçok unsurun bir araya gelmesiyle aynı metinden sayısız olasılıkta oyun sahnelenebilir. Öte yandan, Bernarda Alba'nın Evi bir kere sahneye uyarlandıktan sonra, o oyunu izlemiş olan bir başka yönetmenin, onu izlememiş gibi davranması mümkün değildir, bir kere sahnelenen oyunun imgeleri onun zihnine 
açılmıştır. O yönetmenin ortaya koyacağı uyarlama, önceki metnin imgelem dünyasından izler taşımaktadır. Ve sırasıyla sahnelenecek tüm oyunlar benzer bir sürecin içinde olacaklardır.

Aynı metni sinemaya uyarlamak isteyen bir ekipte de tıpkı oyunun sahnelenmesindeki eşit etki gibi bir yapım süreci söz konusudur. Senaristin Bernarda Alba'nın Evi'ni nasıl senaryolaştırdığı, yönetmenin nasıl görselleştirdiği ve benzeri bütün süreçler zaman-uzamın oluşumunda etkin rol oynarlar. Tam da bu nedenle her yeni yapım yepyeni ve bambaşkadır. Aynı zamanda sinematografinin kendine ait yöntemleri, ara yüzleri ve tekniği dolayısıyla da ortaya çıan metin bambaşka bir şeydir.

Mesela romanda mükemmel olan bazı fikirler, sinemada da mükemmel fikirler olabilirler. Ama kesin olarak havaları birbirinden farklıdır. Diğer taraftan, sinemada sadece sinematografik olan fikirler vardir. Sinemada, romanda da değer bulmuş fikirler söz konusu olsa bile, bu fikirlerin daha şimdiden sinematografik sürece adanmış olduklarını, ona ait olduklarını söyleyeceğiz (Deleuze, 2003: 25).

Ancak yine belirtmek gerekir ki, tam sadakat kavrayışıyla, sinemanın olanaklarından feragat etme pahasına kaynak metne bağlllık gösteren yapıtlar bu yeni yaratım niteliğinin dışında yer almaktadır. Sinemanın ilk yıllarındaki örneklere bakıldığında, doğrudan kayda alınan tiyatro oyunlarını hatırlamakta bu noktada yarar vardır.

Teknik anlamda o tarz bir sinema metni de kesinlikle yazınsal metinden kiplik bakımından farklıdır ancak yaratıcı sinematografik kullanım söz konusu olmadığı sürece, yaratıcı ve özgün bir metin sayılamaz.

Bernarda Alba'nın Evi'nden uyarlanan diğer filmleri izlemiş olan yönetmense artık onların imgelemiyle kendi imgelemini kaynaştırmıştır. Kendi ortaya koyacağı yapıtı da ona benzer ya da taban tabana zit ürettiğinde bile onun etkisinde olduğunu söylemek mümkündür. Aynı biçimde, Bernarda Alba' nın Evi' nin hem oyununu hem de filmini izlemiş olan izleyici de izlediği metinlere bir öncekinin etkisiyle yaklaşacaktır. Bu mesele sıklıkla edebi metni okuyup, sonra ondan uyarlama filmi izleyen izleyici için gözlemlenebilir bir durumdur. Sürekli yazınsal metinle ve onunla ilişkiye giren kendi imgelemiyle filmi kıyaslaması kaçınılmazdır.

Görüldüğü üzere imge çok farklı yollardan geçip çok farklı uğrak noktalarda bulunmaktadır. Ayrıca sürecin karmaşıklığı, bu noktada imgenin bu yolculuğunun köktenci bir biçimde ilk yapıta dayandırılmasını da imkânsız kılmaktadır. Deleuze ve Guattari, Kafka'nın metinleri üzerinden imgelerin kurduğu ilişkiyi bir ağ gibi, bir köksap, bir yuva gibi tanımlamaktalardır (Deleuze ve Guattari, 2000).

İşte izleyici tam da bu noktada, imgenin izini sürer. İlk imgeyi aramaksızın, onun dolambaçlı yollarını, küçük kanallarını, patikalarını dolanır, ulaşmak ister, arar. İşte metni çok katmanlı yapan, yaratıcı yapan, derinlikli yapan, özgün ve ilgi çekici yapan budur. Tüm bunlara bakarak uyarlamanın, yeniden yapmanın kesinlikle yaratıcı bir süreç olarak ele alınabileceği söylenebilir. Aynı metinden sınırsız sayıda anlam çıkarılabildiği gibi, sınırsız sayıda uyarlama metin, sınırsız sayıda imge ve zaman-uzam üretilebilir.

\section{Göçebe İmgeler, İçkinlik Düzlemi ve Duende}

Deleuze ve Guattari (2001), içkinlik düzlemini ortaya koyarken, felsefe bağlamında, kavramların bir araya gelerek algılandığı ve kavrandığı bir düzlemden söz etmektedirler. Kavramlar ve düzlemler özdeş değildir ancak birbirlerini tamamlamakta ve var etmektedirler. 
Düzlem aslında kavramların bir araya gelerek oluşturdukları bir alandır. "İçkinlik düzlemi düşünülmüş ya da düşünülebilir bir kavram değil, ama düşüncenin imgesidir; düşünmenin, düşünceyi kullanmanın, düşünce içinde yol almanın ne anlama geldiğine ilişkin olarak düşüncenin kendine verdiği bir imge..." (Deleuze ve Guattari, 2001:40) Bu bağlamda kavramın yerine imge koyulabilir; o halde düzlem, imgelerin bir araya gelerek ortaya koyduğu metnin kendisidir ve her metne içkin bir biçimde oluşur.

İmge, bir göçebedir. Metinlerden metinlere kendine yeni mekânlar bulur, ancak yeri her zaman kaygan ve muğlaktır. Yukarıdaki bölümlerde uzun uzun tartışıldığı üzere, her türlü yapıtı oluşturan, onun bütünlüğünü sağlayan imgelerdir. İzlemeyi/okumayı ve üretmeyi yaratıcı ve dönüştürücü kılan ise bu imgelerin kendi arasındaki hareketin izinin sürülmesidir. Kimi yapıtlarda bir araya gelip yapıtın katmanlarını ortaya koymaları, onların geçici zamanuzamları olarak okunabilir.

Göçebe için, tersine, toprakla olan ilişki yersizyurdsuzluktan geçer, öyle ki, onun yeniden yeriniyurdunu bulması bile yersizyurdsuzluğu üzerinde yapılmaktadır. Burada toprağın kendisi yersizyurdsuzlaşır, öyle ki, göçebe orada toprağını bulur. Toprak toprak olmaktan çıkar ve sadece bir dayanak, basit bir yer haline girer (Deleuze ve Guattari, 1990: 83).

Deleuze'ün içkinlik düzlemi adını verdiği, göçebe imgenin geçici olarak yerliyurtlu hale geldiği alan, her metnin kendine özgü olarak sahip olduğu alandır. Her metnin kendine özgü bir içkinlik düzlemi vardır. Ancak bu tıpkı Aristoteles'ten bu yana gelen gücül ve edimsel ayrımına Bergson'un getirdiği farklı yaklaşımla daha iyi açıklanabilir. Aristoteles'te gücül ve edimsel arasındaki ayrım tohum ve bitki ilişkisine benzerken; Bergson'da çok daha beklenmedik, şaşırtıcı ve rastlantısal bir edimsellik söz konusudur. Bu da virtüelliktir. Bir toprağın, heykel olmasındaki rastlantısallık ve çeşitli olasılıklar virtüeldir (Deleuze, 2010).

Tüm bunlara dayanarak uyarlama meselesine bakıldığında, her farklı bakışın ve yaklaşımın farklı bir içkinlik düzlemi olan metin ortaya koyacağı açıktır. Ancak bu içkinlik düzleminin başkalığı ve biricikliği bütün durumlar için geçerli değildir. Kimi uyarlamaların tohum, domates ilişkisi içinde olduğunu söylemek mümkündür. Deleuze göçebe imgenin geçici yuvasının içkinlik düzlemi olduğunu şu sözlerle ifade etmiştir:

Bütün imgelerin bu sonsuz kümesi bir tür içkinlik düzlemi oluşturur. İmge bu düzlemde, kendinde varolur. İmgenin bu kendindeliği maddedir: İmgenin ardına gizlenmiş bir şey değildir, tam tersine imge ve hareketin mutlak özdeşliğidir. İmge ve hareketin özdeşliği doğrudan doğruya bizi hareketimge ve maddenin özdeşliği sonucuna götürür (Deleuze, 2014: 85).

İşte bu nokta Deleuze ve Bahtin'in kavramlarının uzlaştığı ve çoğaldığı bir noktayı işaret ediyor denebilir. Bahtin'in her metnin kendine özgü biricik olduğunu söylediği zaman-uzamı ile Deleuze'ün içkinlik düzlemi birbirini tamamlar niteliktedir. Her ikisi de metinleri, uzamda salınan imgenin kendine geçici bir yerleşiklik edindiği, bir yuva edindiği alanlar olarak görmektedirler. Yazar/yönetmen uzamdaki imgeyi koparıp ona geçici bir mekân sağlar, okuyucunun/ izleyicinin sürece katılmasıyla beraber ise imge yine zaman-uzamını değiştirir ve bu akış sürekli olarak devam eder.

Zaman-uzam ve içkinlik düzlemi her metnin kendi sahip olduğu ve derinleştirebildiği, imge ilişkilerini kurduğu özgün alandır, metnin kendisi bunlar olmaksızın düşünülemez. Lorca'nın duende kavramı ise, bu kavramları tamamlar niteliktedir. Duende, yaratıcı olandır, farklı olandır, bir his, bir duygudur ve her metinde bulunmaz bir niteliktir. İşte metinleri 
yaratıcı hale getiren o coşku noktasıdır, titreşen imgelerin alımlayıcının imgelemiyle yaptığı bir dans gibidir. Duende, başkalığı, farkı yaratan dokudur.

Duendeyi bulmak için ne bir harita vardır ne de bir yöntem. Duendenin, kanı bir cam firtınası gibi yaktı̆̆l, insan tükettiği, öğrenilmiş bütün o tatl geometriyi reddettiği, üslupları bozduğu, tesellisi olmayan insani acılardan güç aldığı, İngiliz resim sanatının en güzel pembelerinin, kurşuni ve gri tonlarının ustası Goya'ya korkunç zift karasıyla avuçlar ve dizleriyle resim yaptırdığı, Mossèn Cinto Verdaguer'i Pirenelerin, Jorge Manrique'yi Ocaña kură̆ında ölümü beklemeye gönderdiği, Rimbaud'nun zarif bedenine yeşil bir cambaz kıyafeti giydirdiği, Kont Lautréamont'a boulevard şafağında ölü balık gözleri verdiği bilinir sadece (Lorca, 2014).

Duende kavramı aslında, bir metnin sahip olduğu kendine has dokusunu izleyici/ dinleyici/okuyucu ile paylaşarak duygulanıma dönüştürmeyi, yaratmanın şenliğini ortaya koyuyor. Bu nedenle de bu çalışma yapılırken Lorca'nın metinleri seçilmiştir. Lorca uyarlamalarının i kimilerinde duendeyi bulmak, yaratıcı içkinlik düzlemini, virtüeli bulmak son derece zor denebilir. Kimlerinde ise, bir trajedinin sanatsal manada ruha dokunuşu, bir doku yaratılması ve o dokunun tümüyle sinematografik yöntemlerle oluşturulması son derece ilgi çekici bulunmuştur. Duende için biraz da metaforik olarak, imgenin geçici yuvasındaki şenliğidir demek çok da yerinde olacaktır.

\section{Bernarda Alba'nın Evi'nde Tragedyanın Sinematografik Dönüşümü}

Orijinal adı La Casa de Bernarda Alba (Lorca, 1936) olan yapıt, 1936' da yazıldığı halde, ilk defa 1945 yılında sahnelenmiştir. Bir çağdaş tragedya olarak nitelendirilen oyun, şiirsel bir dille kaleme alınmıştır ve alegorik anlamlar taşıyan yoğun bir metin olarak değerlendirilebilir.

Metnin genel olarak karanlık ve boğucu bir atmosferi olduğu söylenebilir. Hikâye İspanya'nın bir köyünde yaşamakta olan Bernarda Alba ve kızlarının başına gelenleri konu alir.

Lorca (1936) açılış sahnesini şu şekilde betimlemiştir:

\footnotetext{
“Bernarda Alba'nın evinde bembeyaz bir oda. Duvarlar beyazdır. Kordonlu püsküllerle arkaya doğru bağlanmış, kenevir perdeleri olan kemerli girişler vardır. Hasır iskemleler. Duvarlarda, perilerle ya da efsanevi krallarla yüklü, olmayacak manzara resimleri. Yazdır. Sahneyi koyu bir sessizlik doldurmaktadır. Perde açıldığında sahne, boştur. Dışarıdan çan sesleri duyulur"
}

Hizmetçi ve evin kahyası Poncia görünürler. Evin hizmetlisi olarak çalışan bu kadınlar, Bernarda' ya olan nefretlerini, son derece iğneleyici ifadelerle dile getirirler. Yer yer çan sesleri duyulmaktadir.

“Arka kapıdan geniş şallara bürünmüş, kara etekli ve yelpazeli, yas tutan kadınlar, ikişer ikişer girmeye başlarlar. Sahne doluncaya dek ağır ağır girerler" (Lorca, 1936) ifadesiyle sahne değişir. İfadeler son derece karanlık ve boğucudur. Bir yas vardır, kızların babası, Bernarda'nın kocası ölmüştür. Metnin içinde bu bunaltıcılık ifadesi gerek parantez içleriyle gerekse diyaloglar arasında geçen biçimi destekleyen sözcüklerle sıklıkla belirtilmiştir.

Babalarının da ölmesiyle beraber evin bütün yönetimi Bernarda Alba'ya geçmiştir. Evde 
ve o köyde zaten hapis hayatı yaşadığı hissedilen kızlar, babalarının ölümüyle daha da derin bir karanlı̆ın içine gömülmüş görünmektedirler. Bernarda muhafazakâr, aşırı korumacı ve otoriter bir annedir. Gerektiğinde şiddetten kaçınmaz. Kadınlarla ilgili bakışı ise, küçümseyici ve ötekileştiricidir. Kızlar ise, içlerinde yanan gençlik ve dışarıya olan özlemleriyle Bernarda'nın katı kuralları karşısında ezilmektedirler. Hala çocuksu coşkuları, inançları ve erkeklere yasak olana karşı özel bir ilgileri vardır.

Kızların kendi içlerinde bastırdıkları duyguları da vardır, oyun içinde yer yer bu ifadeler yer almaktadır. Hikâyenin trajedisi de burada ortaya çıkmaktadır. Özgürlüğüne kavuşmak isteyen kılar ve onların üzerinde güçlü bir otorite figürü olarak anneleri arasında güçlü çatışma söz konusudur. Kimi kızlar durumu kabul etmiş ve ayak uydurmuşlardır, kimileri ise tümüyle reddetmişlerdir. Adela, annenin otoritesini tümüyle reddetmiştir ve ona oyun boyunca karşı gelmektedir. Yer yer yas tutulması gereken evde sevinçler yaşamasıyla, yer yer dışarıya çıkmaya yönelik öfke patlamalarıyla oyun boyunca bu dileğini ifade eder. Oyunda karakter olarak bulunmayan Pepe El Romano, evin büyük kızı Angustias'la evlenecektir. Ancak Angustias çirkin ve yaşlı olarak, Pepe' ye uyumsuz olarak tasvir edilir. İlk kırılma anı, Pepe ile Angustias'ın evleneceği haberiyle gerçekleşir. Buna aşırı tepki veren kardeşler duygularını farklı tonlarda yaşamaktalardır. En büyük tepkiyi ise Adela vermiştir. Bunun nedenini kimse başlarda anlamaz. Ancak bir sorun vardır, Angustias'la beraber evin hizmetçileri de bunun farkındadır. Çünkü Pepe, Angustias'ın penceresinden gece yarısı ayrılmış olmasına rağmen, gece dörtte gittiği işitilmektedir. Sonrasında bir olay daha patlak verir, birisi Angustias'ın odasından, Pepe'nin resmini çalmıştır. Bütün odalar aranır ve resim, Martirio'nun odasından çıkar. Onun da Pepe'ye karşı gizli bir hayranlığı vardır ancak esas büyük kırılma Pepe ile evin en küçüğü Adela'nın bir ilişkisi olduğu öğrenilince gerçekleşir. Bernarda Pepe'yi vurduğunu söyler aslında elinden kaçırmıştır, bunu duyan Adela, başka bir kaçışı olmadığını fark eder ve odasında kendini asar. Oyunun sonunda Bernarda'nın şu sözleri duyulur:

"Ağlamak da yok. ölüme sessiz katlanmak gerekir, bağrına taş basarcasına. Susun! (Kızlardan birine - ) Sakin olun dedim! (Başka bir kıza - ) Gözyaşı yalnız kalınca dökülecek! Yas denizine gömülece ğiz. O, Bernarda Alba'nın en küçüğü̈, kız oğlan kız öldü. İşittiniz mi? Susun, susun, dedim. Susun!" (Lorca, 1936).

Tragedyanın içerik anlamında genel özelliklerini taşıyan bu Lorca metni, kimi okumalara göre 2.Dünya Savaşı esnasında İspanya'nın alegorik bir anlatımı olarak yorumlanmaktadır. Ancak öte yandan, ilk trajedilerde bile çatışan değerlerin, günümüz dünyasında farklı formlarda çatıştırıldığı görülmektedir, özgürlük ve baskı, iktidar ve direnme, hapsolmak ve kaçmak.

Bu çalışmada Bernarda Alba'nın Evi adlı bu oyunun uyarlandığı iki sinema filmi ele alınmıştır. La Casa de Bernarda Alba (Bernarda Alba'nın Evi, Mario Camus, 1987) ve The House of Bernarda Alba (Bernarda Alba'nın Evi, Stuart Bruge, Núria Espert 1991) incelenmek üzere seçilmiş filmlerdir.

The House of Bernarda, birebir metindekiyle aynı sahne ve diyaloglar ile açılmaktadır. Genellikle parantez içi ifadelere sadık kalınmış ve neredeyse onların dışında hiç diyalog ve eylem eklenmemiştir. Genel atmosfer bakımından karanlık ve kasvetli olduğu söylenebilir. Tıpkı Lorca'nın tasvirinde olduğu üzere, beyaz bir salon kullanılmıştır. 


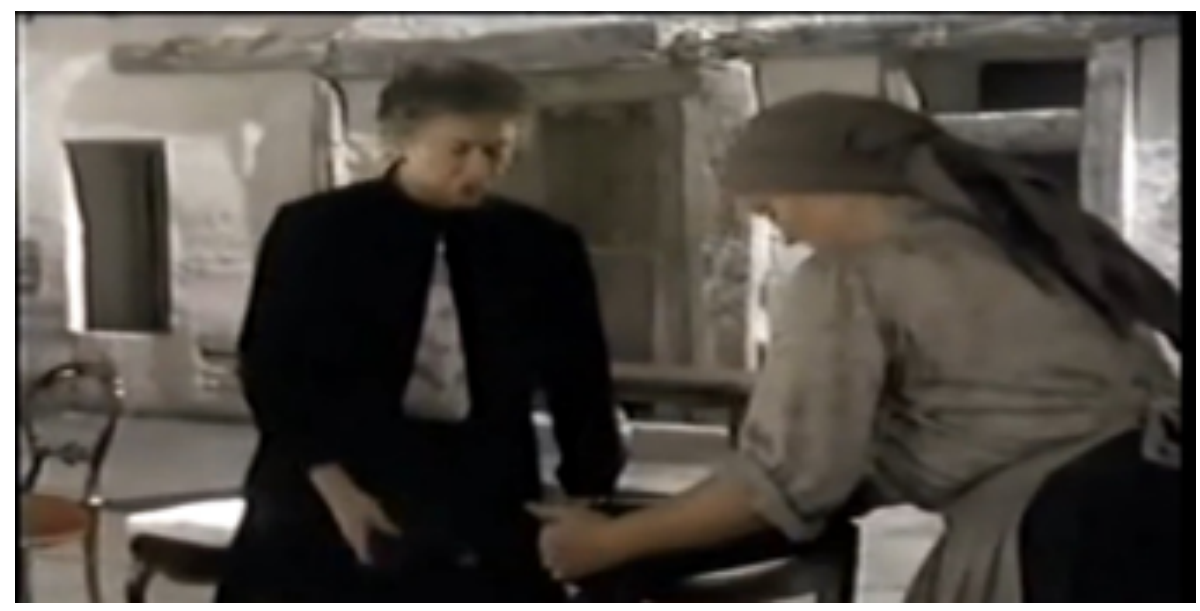

Görsel 1: The House of Bernarda'nın açılış sahnesi.

Karakterler Lorca'nın metninde tasvir edildiği gibi, siyah giyimlilerdir. Kullandıkları eşyalar bakımından yönetmen, biraz daha özgür davranmış ve metinde hiç geçmeyen detayları eklemiştir. Bazı bölümlerde küçük geçişlerde müzik kullanılmıştır. İçerik unsurları bakımından Lorca'nın metnine bağlı kalındığı söylenebilir. Bütün zamansal çizgi birebir sinema perdesine taşınmıştır.

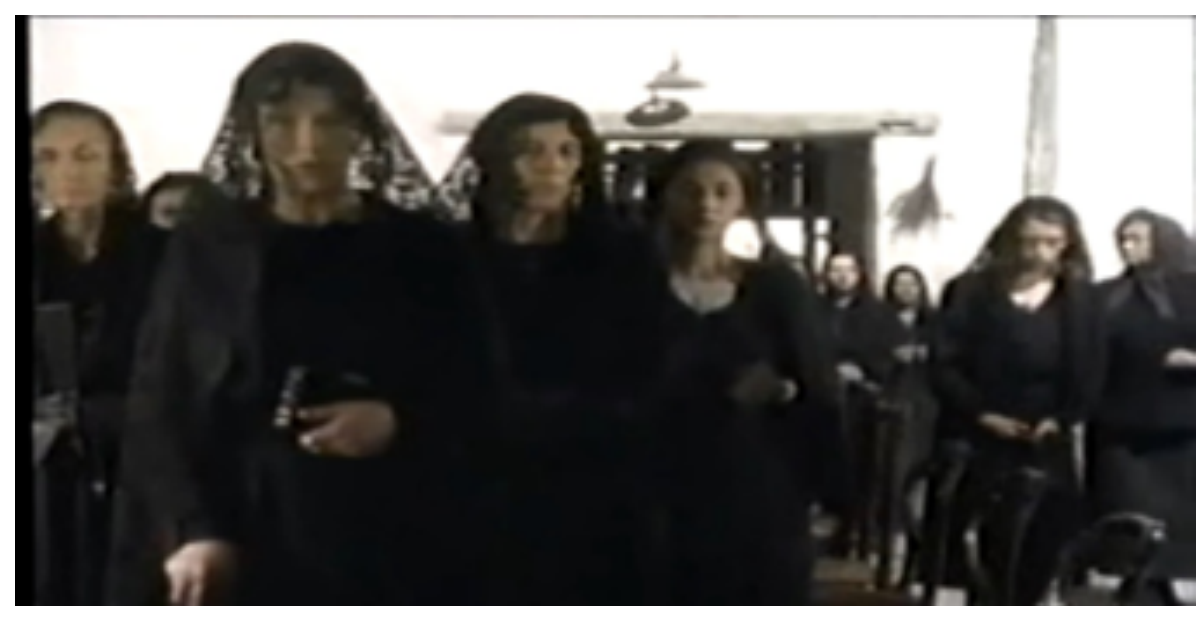

Görsel 2: The House of Bernarda filminde Lorca'nın metnindeki sahnesini birebir karşılayan yas sahnesinden bir kesit.

Zaman-uzam bakımından metne yaklaşıldığında, kamera hareketinin çok az kullanıldığı söylenebilir. Bilinçli olarak mi yoksa bir tiyatro metni olmasından hareket edilmiş olmasından mı bilinmez genellikle bir tiyatro oyunu havası sezilmektedir. Dekor son derece az, sşık kullanımı genellikle flu ve dengelidir. Zaman- mekân değişimlerinde, kesme kullanılmış ve bu noktada yine yazınsal metne sadık kalınmıştır. 


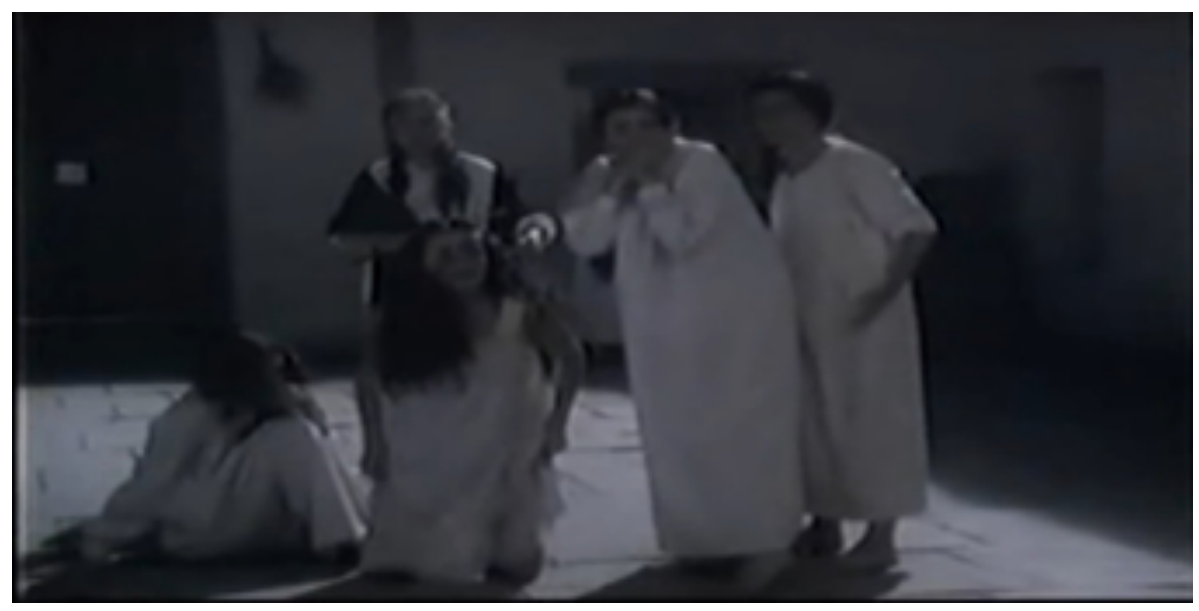

Görsel 3: The House Bernarda filminde Adela'nın intihar ettiği sahneden bir kesit.

Sinematografik unsurlar bakımından zaman-uzamın kullanımı incelendiğinde, filmin bu anlamda zayıf olduğunu söylemek mümkündür. Çünkü metni okumaktan ya da tiyatro sahnesinde izlemekten daha farklı bir bakış açısı, algılanım ya da duygulanım yaşatmayacaksa o uyarlama işlevini bir ölçüde yitirmektedir. Bu noktada tiyatro ile ortaya konabilecek bir imgelemin, sinematografik fikir olmaksızın perdeye aktarılması ne derece gereklidir sorusunu tartışmak gerekir.

(...) ses ile görüntüyü birbirinden koparmak ne açıdan bütünüyle sinematografik bir fikirdir? Bu neden tiyatroda yapılamaz? En azından bir istisna olarak, bu, tiyatroda yapılabilirse, eğer tiyatro bunu yapmanın yolların bulabilirse, tiyatronun bunu sinemadan aldığını söyleyeceğim. O kadar da kötü bir şey değildir bu; görmek ile konuşmak arasındaki kopuşu, ses ile görüntü arasındaki kopuşu sağlamak o denli sinematografik bir fikirdir ki, sinemada bir fikir nedir sorusuna cevap verir (Deleuze, 2003: 31).

İkinci film olarak seçilen Mario Camus'nun uyarlaması, daha başlangıcından bambaşka bir zaman-uzam kurmuştur. Zamansal olarak da filmin başlangıcında, Lorca' nın metninde hiç olmayan, kilisede geçen cenaze sahnesiyle açılmaktadır. Bu, sinemanın zamansal olarak, tıpkı zihnin yaptığı gibi, bütünleyici olarak geçmişi ve geleceği, hiç olmamış ama olabilecek olanı gösterebilmesi ve kendi fikrini üretmesi açısından önemli bir ayrıntı olarak değerlendirilebilir. Açılışta yine metinle koşut olarak çan sesleri duyulmaktadır ancak çan seslerine, dua sesleri eklenmekte ve sonrasında güçlü bir ağıt müziği yükselmektedir. 


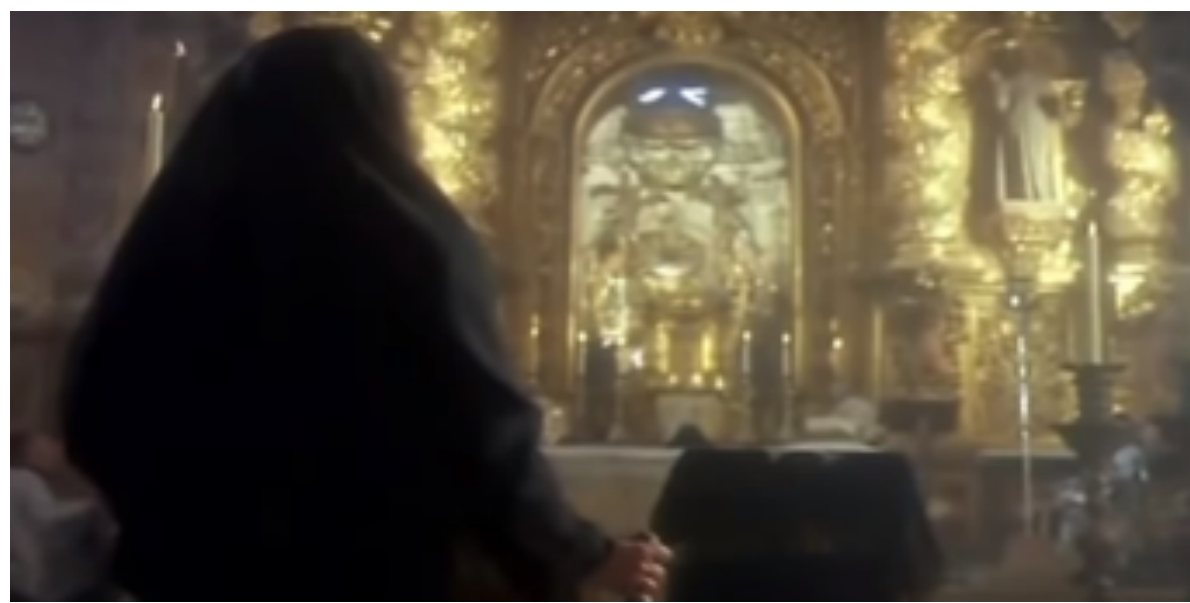

Görsel 4: La Casa de Bernarda Alba filminin kilisede geçen açılış sahnesi.

Öte yandan Camus'nun filminde, imgenin kullanımı sinematografiktir. Sinemaya ait teknikleri kullanarak perspektifler, yakınlaştırmalar ve odaklamalar yapıldı̆̆ı görülmektedir.

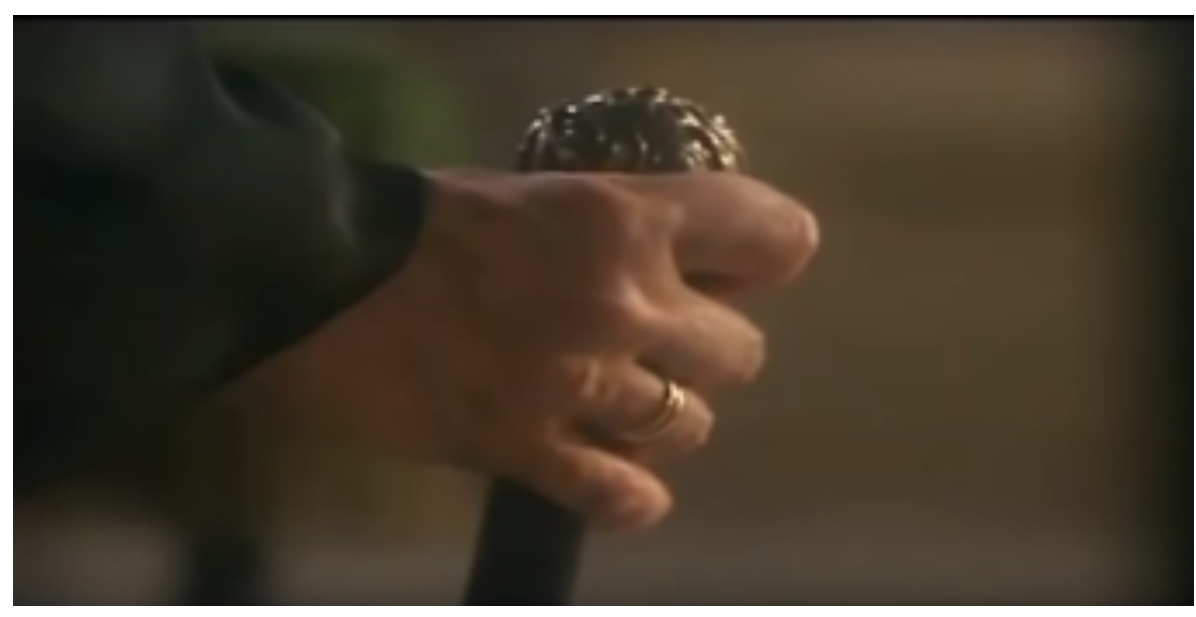

Görsel 5: La Casa de Bernarda Alba'dan bir sahne.

Mekânsal farklılaşma olarak filmde, yine kaynak metinde hiç olmayan dış mekânlar eklenmiş ve filmin boğucu havasına katkıda bulunur nitelikte bu alanlar bile hapishaneyi andırmaktadır. Ana eksende bakıldığında Lorca'nın parantez içlerinde tane tane işlediği atmosferleri tek bir görüntüyle verebilme açısından sinemanın teknik gücünden yararlanıldığ söylenebilir.

Öte yandan filmin kendine özgü bir zamanı vardır, olaylar yine temelde benzer sırayla akmaktadır ancak göstergeler farklılaşmış, olmayan diyaloglar ve sahneler eklenmiştir. Filmin kendi zamanı, kendi ritminde ilerlemekte ve yazılı metnin oluşturduğu o ezici hisleri zamanın yavaş akışıyla da koşut ilerlemektedir. Renk ve ışık kullanımlarındaki değişimlerle de bu süreç desteklenmiştir. 


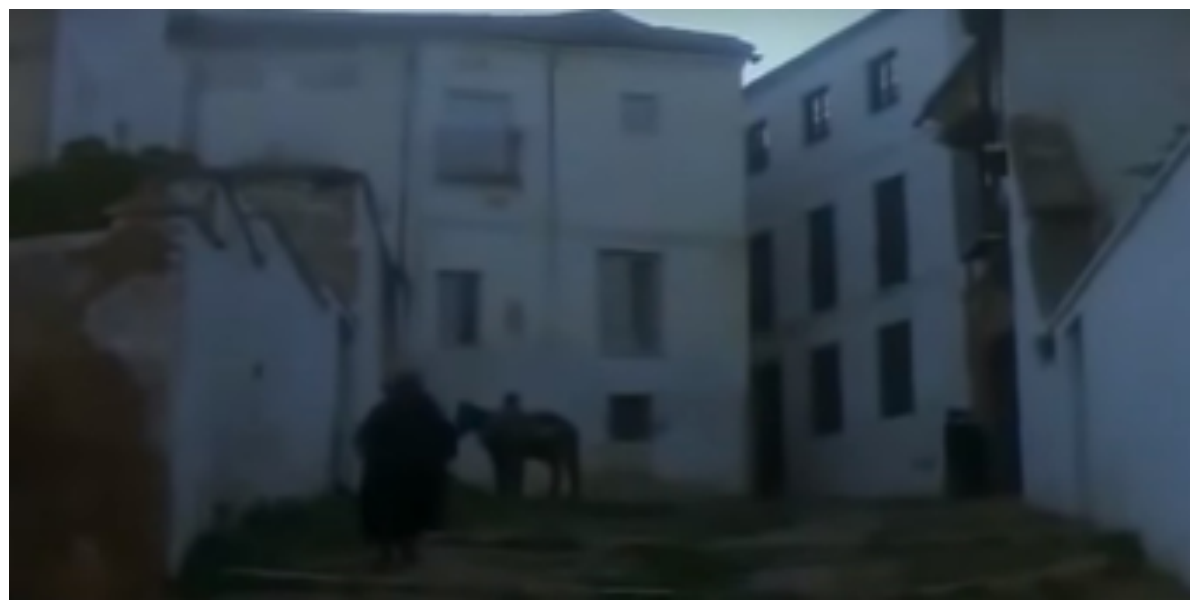

Görsel 6: La Casa de Bernarda Alba filminde dış mekân sahnesinden bir kesit.

Kısaca La Casa De Bernarda Alba filminde, The House of Bernarda Alba'ya kıyasla sinemanın olanaklarından, sinematografik imgeden ve imgelerin birbiri arasındaki serbest etkileşimden daha fazla yararlanılarak çok daha yaratıcı, özgün ve farklı imgelemler üreten bir yapıt ortaya konduğu söylenebilir. Mario Camus'nün filminin bütününde, özgün bir doku, bir coşku ve saf imgenin yoğunluğu hakimdir denebilir.

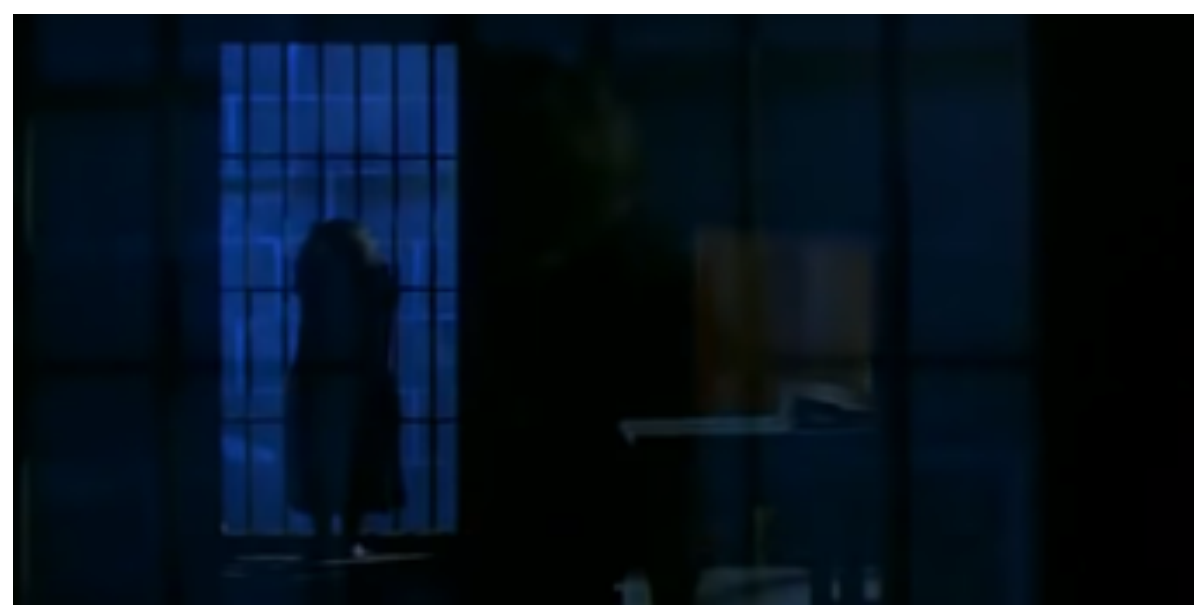

Görsel 7: La Casa de Bernarda filminde Adela'nın intihar sahnesi.

İşte size sinematografik bir fikir. Bu olağanüstüdür, çünkü bu, sinema düzeyinde unsurların gerçek bir dönüşümünü, ve sinemanın bu unsurların fiziksel özellikleriyle karşılıklı ilişkisini bir anda başlatan bir çevrimin ortaya çıkmasını sağlar. Bu bir tür dönüşüm yaratır; bu, hava, toprak, su ve ateşten yola çıkarak unsurların sinemadaki büyük çevrimini başlatır. Bütün bu söylediklerim hikâyeyi ortadan kaldırmıyor. Hikâye hep oradadır, ama bizi çarpan hikâyenin neden bu kadar ilgi çekici olduğudur, yoksa önünde arkasında ne olduğu değil (Deleuze, 2003: 32). 


\section{Sonuç}

Bütün bu kuram eşliğinde filmlerin incelenmesinde temel amaç, uyarlamanın doğal bir süreç olarak insan hayatının bir parçası olduğunu ve yaratıcı bir etkinlik olarak var olduğunu ortaya koyabilmekti.

Uyarlama etkinliğine, sanatlar arası hiyerarşi çerçevesinden bakan kuramsal görüşlerin karşısına, tam tersine her sanat dalının kendi "techne" siyle yaratıcı olanı, duendeye sahip olanı, özgün ve biricik olanı, virtüel olanı ortaya koyabileceği vurgulanmak istendi.

Uyarlama hayatın her yerindedir. Canlılar doğaya uyarlanarak varlıklarını sürdürürler. Zihnin çevresini kavrayışı bile bir uyarlama sürecidir çünkü algı, insanın duyumsadığı her şeyin zihindeki izdüşümüdür. Bu nedenle gün içinde sürekli olarak yapılan bir eylemi, sanat yapıtları bağlamında gerçekleştirirken onu kapalı bir sistem olarak ele alınması kanımca gereksiz bir uğraşıdır. İnsanın var olduğu yerde, biriciklik daima kendini gösterecektir, çünkü herkesin imgelerinin hareketi, içkinlik düzlemi kendine has nitelikler taşır. Nasıl ki okuma eyleminin kendisi kişiye özgü ve biricikse; uyarlama etkinliği de yazarın kaynak metni kavramasına ve onunla kendi bakış açısıyla yeni imgeler üretmesine bağlı olduğundan biricik, tek ve benzersizdir. Geçmişten bu yana, uyarlamayı kaynak metni taklit etmek olarak gören ve onun iyiliğinin ölçütünü benzerlik olarak ele alan kuramsal bakış ve bu bakışın izinde uyarlama yapan yönetmenler olmuştur, olmaya da devam etmektedir. Ancak ortaya koydukları metin, yeni bir perspektif ve imgelem üretmedikçe silinmeye ve yok olmaya mahkumdurlar.

Metinlerarasılık düzlemi özellikle de post yapısalcı bakışla beraber düşünüldüğünde, hayatı yaşamanın bile yaratıcı biçimlerini bulma ihtimalini ortaya koyuyor. Dünyanın ilk çağlarından bu yana sanat yapan, üreten ve bundan beslenen insanın hala bunu sürdürüyor olması, hala yeni bir araya gelmelerin, farklı zaman-uzamların, farklı bakış açılarının olduğunun göstergesi gibi okuyabilmek mümkündür.

Şüphesiz yeni bir metin ortaya koymaya yönelik tüm niyetler, yeni bir içkinlik düzlemi üretirler ancak bu düzende imgelerin birbirleriyle kurduğu ilişki, metnin taşıdığı karmaşık anlamlar dizgesi ve zaman-uzamlar iz sürme duygusunu körüklediği, izleyicinin metne daha çok ve daha içten katılmasını sağladığı sürece ona yeni bir metin denilebilir. Bu çalışmada incelenen iki metne bakıldığında her ikisi de aynı yazınsal metinden hareket etmiş ancak çok farklı sonuçlara ulaşmışlardır. Her iki film de, sinemanın teknolojisini kullanmış olmak ile birlikte Mario Camus' nun filminde sinematografik bir fikir vardır. Orada Camus'nun ruhunu, “duende" sini taşıyan izler vardır. Bu haliyle Camus, Lorca'nın metnini olduğu gibi aktarmamış, onu başkalaştırmış, çoğaltmış, anlamlarını zenginleştirmiştir. Bu bakışa göre uyarlama ancak, kaynak metni beslediğinde, onda fark edilmeyeni ortaya çıkardığında kıymet kazanır.

Belki bu araştırma, bir alımlama çalışmasına da fikir öncülüğü yapabilir. Bu eksende izleyicilerin görüşlerini almak, izleyicilerin duygulanımları üzerine görüşmeler yapmak ve düşünmek ilginç sonuçlar çıkmasını sağlayabilir.

Sinema, düşünce üreten bir sanattır, sinema bir düşünme aracıdır; çünkü düşünceyle benzer imge dönüşümlerine sahiptir. Bu nedenle konu uyarlamalar olsa bile, sinema filminin yeni bir üretim olduğunu; yönetmenin bir yazar olduğunu unutmamak gerekir. Bütün sanatlar ilk ortaya çıtıklarından beri olduğu gibi hala birbirlerini beslemektedirler, bu 
nedenle de aralarında hiyerarşik bir düzen kurup gelenekçi yaklaşmak yerine; teknolojinin de başkalaşmasıyla, onunla daha farklı neler yapılabileceğinin tartışılması belki de yapılması gereken önemli bir mesele olarak görülebilir.

\section{La Casa de Bernarda Alba Film Künyesi}

Y1l: 1987

Yönetmen: Mario Camus

Senaryo: Antonio Larreta, Mario Camus

Yapımc1: Antonio Oliver

Yapım Yeri: İspanya

Süre: 100 Dakika

\section{The House of Bernarda Alba Film Künyesi}

Y11: 1991

Yönetmen: Stuart Burge, Núria Espert

Senaryo: Robert David MacDonald

Yapımc1: Stephen Phillips,

Yapım Yeri: ABD

Süre: 101 Dakika

\section{Kaynakça}

Aktulum, K. (2000). Metinlerarası İlişkiler. Ankara: Öteki.

Aristoteles. (2014). Poetika. (S. Rifat, Çev.) İstanbul: Can.

Bahtin, M. (2014). Karnavaldan Romana. (C. Soydemir, Çev.) İstanbul: Ayrıntı.

Bergson, H. (2015). Madde ve Bellek. (I. Ergüden, Çev.) Ankara: Dost.

Bergson, H. (2015). Madde ve Bellek. (I. Ergüden, Çev.) Ankara: Dost.

Burnett, R. (2012). İmgeler Nasıl Düşünür? (G. Pusar, Çev.) İstanbul: Metis.

Deleuze, G. (2003). İki Konferans. (U. Baker, Çev.) İstanbul: Norgunk.

Deleuze, G. (2010). Bergsonculuk. (H. Yücefer, Çev.) İstanbul: Otonom.

Deleuze, G. (2014). Sinema 1: Hareket İmge. (S. Özdemir, Çev.) İstanbul: Norgunk.

Deleuze, G., \& Guattari, F. (1990). Kapitalizm ve Şizofreni 1: Göçebe Bilimi İncelemesi. 
(A. Akay, Çev.) İstanbul: Bağlam.

Deleuze, G., \& Guattari, F. (2000). Kafka: Minör Bir Edebiyat İçin. (Ö. Uçkan, \& I. Ergüden, Çev.) İstanbul: YKY.

Deleuze, G., \& Guattari, F. (2001). Felsefe Nedir? (T. Ilgaz, Çev.) İstanbul: YKY.

Kula, O. B. (2016). Yazınsal Yapıt ve Ahmet Ümit Nasıl Okunabilir? İstanbul: Everest.

Lorca, F. G. (1936). Bernarda Alba'nın Evi. (T. Oflazoğlu, Çev.)

Lorca, F. G. (2014). Duende' nin Oyunu ve Kuramı. Tiyatro Araştırmaları Dergisi, 2(38).

Nutku, Ö. (2001). Dram Sanatı: Tiyatroya Giriş. İstanbul: Kabalc1.

Oliver, A. (Prodüktör), \& Camus, M. (Yöneten). (1987). La Casa de Bernarda Alba [Sinema Filmi]. İspanya: Paraiso Films S.A.

Phillips, S. (Prodüktör), Bruge, S., \& Espert, N. (Yönetenler). (1991). The House Of Bernarda Alba [Sinema Filmi]. ABD: Thirteen/WNET.

Şener, S. (2016). Yaşamın Kırılma Noktasında Dram Sanatı. Ankara: Dost. 